\title{
HUMAN CHROMOSOMES
}

\author{
Evidence for Autosomal Sexual Dimorphism
}

\author{
CH. J. KOWALSKI, ${ }^{1}$ C. E. NASJLETI ${ }^{2}$ and J. E. HARRIS ${ }^{3}$
}

University of Michigan, 'Dental Research Institute, ${ }^{2}$ Veterans Administration Hospital, and ${ }^{3}$ School of Dentistry, Ann Arbor, MI 48104, USA

\begin{abstract}
SUMMARY
The karyotypes of 100 males and 100 females, each assembled by the trypsin banding method, are examined in a study designed to investigate sex differences among autosomes. It is shown that female autosomes are consistently longer than those of the males, with respect to both the short and long arm measurements. In addition, discriminant analysis is used to distinguish between the male and female karyotypes. We find that, using autosomal measurements alone, this can be done with a high probability of success.
\end{abstract}

Variations in the human karyotype associated with sexual abnormalities, congenital anomalies and mental retardation have received much attention in the literature [3]. Variations that have no association with developmental abnormalities or genetic diseases have been described less frequently [7], despite the fact that several areas of research demand accurate knowledge of the normal human karyotype [2]. In particular, sexual dimorphism has been the object of but limited study. Thus, Penrose [12], in presenting one of the first statistical descriptions of somatic chromosomes, pooled the male and female samples. Turpin \& Lejeune [14] provided separate male and female descriptions, but did not formally consider sexual dimorphism. Bender \& Kastenbaum [2] compared the male and female samples for the relative lengths of the short and long arms of each of the autosomes, but found significant differences only for the number 8 and the $\mathrm{X}$ chromosomes; and they attributed these more to the method of identifying the $\mathrm{X}$ chromosome in the cell metaphases than to sexual dimorphism. They stated: "In spite of these differences, it seems useful and legitimate to pool the male and female data for a statement of the average normal karyotype of human beings, regardless of sex."

Thus although certain karyotypic sex differences are known to exist $[1,5]$ it appears that most cytologists do not consider there to be any sexual dimorphism with respect to measurements designed to reflect chromosomal size and shape. We became interested in re-examining this question several years ago when some evidence in favor of autosomal sexual dimorphism emerged from chromosomal measurements being collected for an entirely different purpose [4]. We studied autosomal measurements made from the karyotypes of 100 nor- 
Table 1. Sex-specific means and standard deviations for the short and long arms of each of the 22 autosomes computed on the basis of 66 male and 34 female cells

\begin{tabular}{|c|c|c|c|c|c|c|c|c|}
\hline \multirow{3}{*}{$\begin{array}{l}\text { Chromo- } \\
\text { some } \\
\text { no. }\end{array}$} & \multicolumn{4}{|c|}{ Short arm } & \multicolumn{4}{|c|}{ Long arm } \\
\hline & \multicolumn{2}{|l|}{ Male } & \multicolumn{2}{|c|}{ Female } & \multicolumn{2}{|l|}{ Male } & \multicolumn{2}{|c|}{ Female } \\
\hline & Mean & S.D. & Mean & S.D. & Mean & S.D. & Mean & S.D. \\
\hline 1 & 13.28 & 3.04 & 15.06 & 2.11 & 14.40 & 3.14 & 16.87 & 2.28 \\
\hline 2 & 10.21 & 2.30 & 11.53 & 1.47 & 16.10 & 3.89 & 17.99 & 2.59 \\
\hline 3 & 10.39 & 2.36 & 11.52 & 2.25 & 11.71 & 2.56 & 13.06 & 1.84 \\
\hline 4 & 6.26 & 0.97 & 7.00 & 1.01 & 14.82 & 3.25 & 16.89 & 2.56 \\
\hline 5 & 5.80 & 0.96 & 6.42 & 0.95 & 13.76 & 2.96 & 15.53 & 2.00 \\
\hline 6 & 7.50 & 1.39 & 8.50 & 1.34 & 11.74 & 2.43 & 13.23 & 2.27 \\
\hline 7 & 6.48 & 1.13 & 7.44 & 1.10 & 10.63 & 2.34 & 11.85 & 1.87 \\
\hline 8 & 6.61 & 1.02 & 6.90 & 0.92 & 9.64 & 2.14 & 11.10 & 1.81 \\
\hline 9 & 5.25 & 0.86 & 5.80 & 0.60 & 10.45 & 2.16 & 11.55 & 1.56 \\
\hline 10 & 5.66 & 1.04 & 5.90 & 0.91 & 9.51 & 1.94 & 10.85 & 1.44 \\
\hline 11 & 6.33 & 1.10 & 6.59 & 1.20 & 8.45 & 1.71 & 9.65 & 1.24 \\
\hline 12 & 4.59 & 0.74 & 5.01 & 0.75 & 9.55 & 2.07 & 10.55 & 1.51 \\
\hline 13 & 2.39 & 0.53 & 2.32 & 0.60 & 10.70 & 2.95 & 11.53 & 1.55 \\
\hline 14 & 2.37 & 0.57 & 2.69 & 0.63 & 9.70 & 1.84 & 10.62 & 1.47 \\
\hline 15 & 2.08 & 1.16 & 2.21 & 0.60 & 8.80 & 1.60 & 9.76 & 1.58 \\
\hline 16 & 4.88 & 0.72 & 6.50 & 7.29 & 6.89 & 1.67 & 7.83 & 1.28 \\
\hline 17 & 3.63 & 0.65 & 3.98 & 0.71 & 6.93 & 1.20 & 9.92 & 12.86 \\
\hline 18 & 2.94 & 0.51 & 3.20 & 0.54 & 6.63 & 1.19 & 7.18 & 0.94 \\
\hline 19 & 4.29 & 0.67 & 4.58 & 0.73 & 5.29 & 0.83 & 5.52 & 0.65 \\
\hline 20 & 3.80 & 0.61 & 4.06 & 0.72 & 4.75 & 0.70 & 5.00 & 0.69 \\
\hline 21 & 2.01 & 0.55 & 2.34 & 0.63 & 5.08 & 0.67 & 5.46 & 0.72 \\
\hline 22 & 1.57 & 0.48 & 1.77 & 0.48 & 4.56 & 0.64 & 4.84 & 0.66 \\
\hline
\end{tabular}

mal individuals (66 males and 34 females) and found that with the sole exception of the short arm of chromosome number 13, the mean values of the short and long arm measurements for the females were consistently longer than the corresponding measurements for the males. The means and standard deviations for the short and long arms of the 22 autosomes are shown in table 1. Here the unit of measurement is $\mathrm{mm}$, i.e., the means and standard deviations shown are for measurements made from photographs of the metaphase figures, these being produced with a magnification of 8000 diameters [4]. Standardized measurements for the 200 cells utilized in the present investigation are given later-the direct measurements shown in table 1 are offered only as an indication of the data that first alerted us to the possibility of autosomal sexual dimorphism.

In addition to the evidence contained in table 1, we used discriminant analysis to test the significance of these differences and to assess the accuracy with which it was possible to distinguish between males and females. The means were indeed significantly different and we found that 60 of the males were (correctly) classified as male and 6 (incorrectly) classified as female. Of the 34 females, 32 were classified as female and only 2 misclassified as male. However, this evidence did not allow us to demonstrate the existence of autosomal sexual dimorphism. (1) The study was not designed to test this hypothesis; we did not, e.g., include equal numbers of male and female cells. While this is not necessary to 
perform tests of significance and/or discriminant analyses, these procedures may be expected to operate most efficiently when this simple condition is satisfied [6].

(2) No attempt was made to record the measurements in a blind fashion. While the fact that we were concentrating on other aspects of these karyotypes probably avoided any bias in this connection, only a carefully controlled, blind study could insure lack of bias in the measurement procedure. (3) And perhaps most importantly, the karyotypes were produced in the then standard manner of "pairing off" homologous pairs of chromosomes according to size [11]. It was felt that any re-examination of this question should be based on the new banding methods so that the homologous pairs of chromosomes could be unambiguously identified.

Thus the present study was designed to investigate autosomal sexual dimorphism on the basis of data collected expressly for this purpose and controlling for the factors alluded to above.

\section{METHODS AND MATERIALS}

The present study is based on cells cultured from the peripheral blood of 100 males and 100 females. Each of these individuals were normal, healthy people between 20 and 40 years of age; most of them were employed at the Veterans Administration Hospital in Ann Arbor. Mich. These cultures were processed following the technique of Moorhead et al. [8]. The slight modifications introduced by us to this method have been documented elsewhere [9]. The chromosomes were stained with Giemsa and the banding patterns were obtained using the "trypsin method" of Seabright [13].

Photomicrographs were taken by an oil-immersion lens with a magnification of 90 diameters and an eyepiece magnification of 10 diameters. These negatives produced prints with a final magnification of approx. 8000 diameters. After photography, the best cell metaphases were selected for readability, absence of overlapping and comparability of the attained stage of colcemid-mitosis. Individual chromosomes were cut out from each print and mounted on a card with the homologous chromosome pairs numbered and grouped following the scheme recommended by the Paris Conference [10]. The male and female cells were processed at random and a single batch of colcemid was used to harvest all of the 200 cells.

Chromosome measurements, as devised by Harris et al. [4], was employed in this study. The lengths of the short $\left(M_{1}\right)$ and long $\left(M_{2}\right)$ arms of each of the autosomes were recorded. We also computed the length of the chromosome $\left(M_{3}=M_{1}+M_{2}\right)$ : the ratio of the short arm to the long arm $\left(M_{4}=M_{1} / M_{2}\right)$; the centromere index $\left(M_{5}=M_{1} / M_{3}\right)$; and the relative lengths of the short and long arms of each chromosome which represents the individual chromosome as a percentage of the sum of the lengths of the chromosome complement, excluding the sex chromosomes.

\section{RESULTS}

Table 2 gives the sex-specific mean values of the measurements defined above for each of the 22 autosomes.

Concentrating first on the (absolute) length of the chromosomes, it is seen that the average value for the female cells is consistently longer than that of the male cells. And this is mirrored in both the short and long arm: With the single exception of the short arm of chromosome number 19 , the arms of the female autosomes are longer than the corresponding arms for the male autosomes.

Differences in chromosomal shape as measured by the arm ratio and centromere index are less apparent. There is no obvious, consistent pattern of differences which can be used to distinguish between the male and female cells. While there are some definite indications of differences within certain of the chromosomal groups, viz., in the D and $G$ groups, these are not so easily interpreted as the consistent differences in the size of the autosomes. Nonetheless, for these five chromosomes, the females have significantly higher arm ratios, i.e., the short arms of the female chromosomes are longer relative to their long arms than in the male cells.

Even fewer differences are in evidence among the relative measurements. This is, of course, to be expected in the context of 
Table 2. Sex-specific mean values for eight measurements made on each of the 22 autosomes for 100 male and 100 female cells

\begin{tabular}{|c|c|c|c|c|c|c|c|c|c|}
\hline \multirow{2}{*}{$\begin{array}{l}\text { Chromo- } \\
\text { some } \\
\text { no. }\end{array}$} & \multirow{2}{*}{ Sex } & \multicolumn{3}{|c|}{ Direct measurements } & \multicolumn{2}{|c|}{ Ratios } & \multicolumn{3}{|c|}{ Rel. measurements } \\
\hline & & $\begin{array}{l}\text { Short } \\
\text { arm }\end{array}$ & $\begin{array}{l}\text { Long } \\
\text { arm }\end{array}$ & $\begin{array}{l}\text { Total } \\
\text { length }\end{array}$ & $\begin{array}{l}\text { Arm } \\
\text { ratio }\end{array}$ & $\begin{array}{l}\text { Centromere } \\
\text { index }\end{array}$ & $\begin{array}{l}\text { Short } \\
\text { arm }\end{array}$ & $\begin{array}{l}\text { Long } \\
\text { arm }\end{array}$ & $\begin{array}{l}\text { Total } \\
\text { length }\end{array}$ \\
\hline 1 & $\begin{array}{l}0 \\
\text { o }\end{array}$ & $\begin{array}{l}14.09 \\
14.37\end{array}$ & $\begin{array}{l}14.90 \\
15.84\end{array}$ & $\begin{array}{l}28.99 \\
30.21\end{array}$ & $\begin{array}{l}0.946 \\
0.908\end{array}$ & $\begin{array}{l}48.6 \\
47.6\end{array}$ & $\begin{array}{l}4.13 \\
4.00\end{array}$ & $\begin{array}{l}4.36 \\
4.42\end{array}$ & $\begin{array}{l}8.49 \\
8.42\end{array}$ \\
\hline 2 & $\begin{array}{l}\sigma \\
\delta \\
q\end{array}$ & $\begin{array}{l}10.75 \\
11.29\end{array}$ & $\begin{array}{l}16.20 \\
16.77\end{array}$ & $\begin{array}{l}26.95 \\
28.06\end{array}$ & $\begin{array}{l}0.665 \\
0.675\end{array}$ & $\begin{array}{l}39.9 \\
40.3\end{array}$ & $\begin{array}{l}3.17 \\
3.15\end{array}$ & $\begin{array}{l}4.74 \\
4.67\end{array}$ & $\begin{array}{l}7.91 \\
7.82\end{array}$ \\
\hline 3 & $\begin{array}{l}\delta \\
\phi \\
q\end{array}$ & $\begin{array}{l}11.07 \\
11.54\end{array}$ & $\begin{array}{l}12.17 \\
12.54\end{array}$ & $\begin{array}{l}23.24 \\
24.08\end{array}$ & $\begin{array}{l}0.913 \\
0.921\end{array}$ & $\begin{array}{l}47.7 \\
47.9\end{array}$ & $\begin{array}{l}3.24 \\
3.22\end{array}$ & $\begin{array}{l}3.56 \\
3.50\end{array}$ & $\begin{array}{l}6.80 \\
6.72\end{array}$ \\
\hline 4 & $\begin{array}{l}q \\
q \\
q\end{array}$ & $\begin{array}{l}6.09 \\
6.36\end{array}$ & $\begin{array}{l}15.06 \\
15.60\end{array}$ & $\begin{array}{l}21.15 \\
21.96\end{array}$ & $\begin{array}{l}0.409 \\
0.411\end{array}$ & $\begin{array}{l}28.9 \\
29.0\end{array}$ & $\begin{array}{l}1.79 \\
1.78\end{array}$ & $\begin{array}{l}4.41 \\
4.35\end{array}$ & $\begin{array}{l}6.20 \\
6.13\end{array}$ \\
\hline 5 & $\begin{array}{l}0 \\
0 \\
q\end{array}$ & $\begin{array}{l}6.03 \\
6.38\end{array}$ & $\begin{array}{l}14.66 \\
15.30\end{array}$ & $\begin{array}{l}20.69 \\
21.68\end{array}$ & $\begin{array}{l}0.416 \\
0.420\end{array}$ & $\begin{array}{l}29.3 \\
29.5\end{array}$ & $\begin{array}{l}1.77 \\
1.78\end{array}$ & $\begin{array}{l}4.29 \\
4.26\end{array}$ & $\begin{array}{l}6.06 \\
6.04\end{array}$ \\
\hline 6 & $\begin{array}{l}0 \\
0 \\
9\end{array}$ & $\begin{array}{l}8.03 \\
8.35\end{array}$ & $\begin{array}{l}12.12 \\
12.70\end{array}$ & $\begin{array}{l}20.15 \\
21.05\end{array}$ & $\begin{array}{l}0.665 \\
0.662\end{array}$ & $\begin{array}{l}39.9 \\
39.8\end{array}$ & $\begin{array}{l}2.36 \\
2.33\end{array}$ & $\begin{array}{l}3.55 \\
3.54\end{array}$ & $\begin{array}{l}5.91 \\
5.87\end{array}$ \\
\hline 7 & $\begin{array}{l}0 \\
0 \\
q\end{array}$ & $\begin{array}{l}7.15 \\
7.55\end{array}$ & $\begin{array}{l}11.05 \\
11.41\end{array}$ & $\begin{array}{l}18.20 \\
18.96\end{array}$ & $\begin{array}{l}0.653 \\
0.668\end{array}$ & $\begin{array}{l}39.4 \\
39.9\end{array}$ & $\begin{array}{l}2.10 \\
2.11\end{array}$ & $\begin{array}{l}3.24 \\
3.18\end{array}$ & $\begin{array}{l}5.34 \\
5.29\end{array}$ \\
\hline 8 & $\begin{array}{l}0 \\
0 \\
0\end{array}$ & $\begin{array}{l}6.00 \\
6.19\end{array}$ & $\begin{array}{l}10.84 \\
11.14\end{array}$ & $\begin{array}{l}16.84 \\
17.33\end{array}$ & $\begin{array}{l}0.557 \\
0.560\end{array}$ & $\begin{array}{l}35.7 \\
35.8\end{array}$ & $\begin{array}{l}1.76 \\
1.73\end{array}$ & $\begin{array}{l}3.18 \\
3.11\end{array}$ & $\begin{array}{l}4.94 \\
4.84\end{array}$ \\
\hline 9 & $\begin{array}{l}0 \\
0 \\
+\end{array}$ & $\begin{array}{l}6.42 \\
6.55\end{array}$ & $\begin{array}{r}9.73 \\
10.34\end{array}$ & $\begin{array}{l}16.15 \\
16.89\end{array}$ & $\begin{array}{l}0.667 \\
0.646\end{array}$ & $\begin{array}{l}39.9 \\
39.0\end{array}$ & $\begin{array}{l}1.89 \\
1.84\end{array}$ & $\begin{array}{l}2.85 \\
2.87\end{array}$ & $\begin{array}{l}4.74 \\
4.71\end{array}$ \\
\hline 10 & $\begin{array}{l}0 \\
0 \\
9\end{array}$ & $\begin{array}{l}5.69 \\
5.99\end{array}$ & $\begin{array}{l}10.32 \\
10.74\end{array}$ & $\begin{array}{l}16.01 \\
16.73\end{array}$ & $\begin{array}{l}0.556 \\
0.574\end{array}$ & $\begin{array}{l}35.6 \\
36.0\end{array}$ & $\begin{array}{l}1.68 \\
1.68\end{array}$ & $\begin{array}{l}3.03 \\
3.00\end{array}$ & $\begin{array}{l}4.71 \\
4.68\end{array}$ \\
\hline 11 & $\begin{array}{l}0 \\
0 \\
9\end{array}$ & $\begin{array}{l}5.86 \\
6.24\end{array}$ & $\begin{array}{r}9.86 \\
10.39\end{array}$ & $\begin{array}{l}15.72 \\
16.63\end{array}$ & $\begin{array}{l}0.610 \\
0.609\end{array}$ & $\begin{array}{l}37.8 \\
37.6\end{array}$ & $\begin{array}{l}1.72 \\
1.75\end{array}$ & $\begin{array}{l}2.89 \\
2.90\end{array}$ & $\begin{array}{l}4.61 \\
4.65\end{array}$ \\
\hline 12 & $\begin{array}{l}0 \\
0 \\
q\end{array}$ & $\begin{array}{l}4.91 \\
5.28\end{array}$ & $\begin{array}{l}10.99 \\
11.18\end{array}$ & $\begin{array}{l}15.90 \\
16.46\end{array}$ & $\begin{array}{l}0.453 \\
0.480\end{array}$ & $\begin{array}{l}31.0 \\
32.1\end{array}$ & $\begin{array}{l}1.45 \\
1.48\end{array}$ & $\begin{array}{l}3.22 \\
3.12\end{array}$ & $\begin{array}{l}4.67 \\
4.60\end{array}$ \\
\hline 13 & $\begin{array}{l}0 \\
0 \\
0\end{array}$ & $\begin{array}{l}2.30 \\
2.99\end{array}$ & $\begin{array}{l}10.28 \\
10.80\end{array}$ & $\begin{array}{l}12.58 \\
13.79\end{array}$ & $\begin{array}{l}0.228 \\
0.278\end{array}$ & $\begin{array}{l}18.3 \\
21.5\end{array}$ & $\begin{array}{l}0.68 \\
0.83\end{array}$ & $\begin{array}{l}3.02 \\
3.02\end{array}$ & $\begin{array}{l}3.70 \\
3.85\end{array}$ \\
\hline 14 & $\begin{array}{l}0 \\
q \\
q\end{array}$ & $\begin{array}{l}2.28 \\
2.80\end{array}$ & $\begin{array}{r}9.51 \\
10.16\end{array}$ & $\begin{array}{l}11.79 \\
12.96\end{array}$ & $\begin{array}{l}0.245 \\
0.276\end{array}$ & $\begin{array}{l}19.3 \\
21.4\end{array}$ & $\begin{array}{l}0.68 \\
0.78\end{array}$ & $\begin{array}{l}2.79 \\
2.84\end{array}$ & $\begin{array}{l}3.47 \\
3.62\end{array}$ \\
\hline 15 & $\begin{array}{l}0 \\
\$ \\
q\end{array}$ & $\begin{array}{l}2.25 \\
2.81\end{array}$ & $\begin{array}{r}9.47 \\
10.03\end{array}$ & $\begin{array}{l}11.72 \\
12.84\end{array}$ & $\begin{array}{l}0.242 \\
0.283\end{array}$ & $\begin{array}{l}19.2 \\
21.8\end{array}$ & $\begin{array}{l}0.67 \\
0.79\end{array}$ & $\begin{array}{l}2.78 \\
2.80\end{array}$ & $\begin{array}{l}3.45 \\
3.59\end{array}$ \\
\hline 16 & $\stackrel{0}{q}$ & $\begin{array}{l}4.89 \\
5.07\end{array}$ & $\begin{array}{l}6.79 \\
7.25\end{array}$ & $\begin{array}{l}11.68 \\
12.32\end{array}$ & $\begin{array}{l}0.724 \\
0.706\end{array}$ & $\begin{array}{l}41.9 \\
41.2\end{array}$ & $\begin{array}{l}1.44 \\
1.42\end{array}$ & $\begin{array}{l}2.00 \\
2.02\end{array}$ & $\begin{array}{l}3.44 \\
3.44\end{array}$ \\
\hline 17 & $\begin{array}{l}0 \\
q \\
q\end{array}$ & $\begin{array}{l}3.88 \\
4.06\end{array}$ & $\begin{array}{l}7.10 \\
7.45\end{array}$ & $\begin{array}{l}10.98 \\
11.51\end{array}$ & $\begin{array}{l}0.551 \\
0.552\end{array}$ & $\begin{array}{l}35.3 \\
35.3\end{array}$ & $\begin{array}{l}1.15 \\
1.14\end{array}$ & $\begin{array}{l}2.09 \\
2.08\end{array}$ & $\begin{array}{l}3.24 \\
3.22\end{array}$ \\
\hline 18 & $\begin{array}{l}0 \\
0\end{array}$ & $\begin{array}{l}3.45 \\
3.64\end{array}$ & $\begin{array}{l}6.81 \\
7.34\end{array}$ & $\begin{array}{l}10.26 \\
10.98\end{array}$ & $\begin{array}{l}0.512 \\
0.500\end{array}$ & $\begin{array}{l}33.7 \\
33.2\end{array}$ & $\begin{array}{l}1.02 \\
1.02\end{array}$ & $\begin{array}{l}2.01 \\
2.06\end{array}$ & $\begin{array}{l}3.03 \\
3.08\end{array}$ \\
\hline 19 & $\begin{array}{l}\delta \\
\vdots \\
+\end{array}$ & $\begin{array}{l}4.26 \\
4.20\end{array}$ & $\begin{array}{l}5.18 \\
5.44\end{array}$ & $\begin{array}{l}9.44 \\
9.64\end{array}$ & $\begin{array}{l}0.831 \\
0.776\end{array}$ & $\begin{array}{l}45.1 \\
43.5\end{array}$ & $\begin{array}{l}1.27 \\
1.18\end{array}$ & $\begin{array}{l}1.52 \\
1.52\end{array}$ & $\begin{array}{l}2.79 \\
2.70\end{array}$ \\
\hline 20 & $\begin{array}{l}0 \\
9 \\
9\end{array}$ & $\begin{array}{l}4.18 \\
4.34\end{array}$ & $\begin{array}{l}4.99 \\
5.15\end{array}$ & $\begin{array}{l}9.17 \\
9.49\end{array}$ & $\begin{array}{l}0.846 \\
0.849\end{array}$ & $\begin{array}{l}45.7 \\
45.7\end{array}$ & $\begin{array}{l}1.24 \\
1.22\end{array}$ & $\begin{array}{l}1.47 \\
1.44\end{array}$ & $\begin{array}{l}2.71 \\
2.66\end{array}$ \\
\hline 21 & $\begin{array}{l}8 \\
9\end{array}$ & $\begin{array}{l}1.96 \\
2.42\end{array}$ & $\begin{array}{l}4.27 \\
4.48\end{array}$ & $\begin{array}{l}6.23 \\
6.90\end{array}$ & $\begin{array}{l}0.462 \\
0.541\end{array}$ & $\begin{array}{l}31.0 \\
34.7\end{array}$ & $\begin{array}{l}0.58 \\
0.68\end{array}$ & $\begin{array}{l}1.26 \\
1.26\end{array}$ & $\begin{array}{l}1.84 \\
1.94\end{array}$ \\
\hline 22 & $\begin{array}{l}0 \\
0 \\
0 \\
0\end{array}$ & $\begin{array}{l}2.42 \\
2.69\end{array}$ & $\begin{array}{l}4.48 \\
4.94\end{array}$ & $\begin{array}{l}6.90 \\
7.63\end{array}$ & $\begin{array}{l}0.541 \\
0.553\end{array}$ & $\begin{array}{l}34.7 \\
35.1\end{array}$ & $\begin{array}{l}0.68 \\
0.75\end{array}$ & $\begin{array}{l}1.26 \\
1.38\end{array}$ & $\begin{array}{l}1.94 \\
2.13\end{array}$ \\
\hline
\end{tabular}


Table 3. Results of the discriminant function analysis when the direct measurements of the short arms of the chromosomes are used as the set of discriminating variables

\begin{tabular}{llll}
\hline & Male & Female & Total \\
\hline Male & 76 & 24 & 100 \\
Female & 30 & 70 & 100 \\
Mahalanobis & & & \\
Distance & $F$-statistic & $P$-value \\
1.36 & 2.77 & 0.0001 \\
\hline
\end{tabular}

size differences: The very use of relative measures cancels out size differences by design. While this may be desirable in making the results of different laboratories comparable, the use of relative measurements negates differences in size irrespective of the source of these differences. In particular, the use of relative measurements could have masked sex differences in size in other investigations.

We turn now to the results of the discriminant function analyses which have as their aim the estimation of the extent to which male and female cells can be distinguished on the basis of autosomal measurements. In addition, tests of the significance of the differences in the mean values for the males and females are provided. The use of this technique in a cytogenetic context was illustrated by Harris et al. [4]. A more general discussion was given by Kowalski [6]. Table 3 gives the results when the direct short arm measurements were used as the set of discriminating variables. It is seen that $76 \%$ of the male cells were correctly classified as male; while $24 \%$ were misclassified as being female. Similarly, $70 \%$ of the female cells were correctly classified and $30 \%$ misclassified. The Mahalanobis distance (sometimes called the $D^{2}$-statistic) is a measure of the distance be- tween the mean values of the distribution of these variables in the male and female samples and, in the two group case, is simply related to Hotelling's $T^{2}$-statistic which is used to test the hypothesis that the mean values of the set of discriminating variables are the same for the males and females [6]. The $F$-statistic used to test this hypothesis and the associated $P$-value are also given. When different sets of variables are used in subsequent discriminant analyses, the Mahalanobis distance may be used to compare the discriminating power of these different sets of variables; the larger the distance, the more the mean values of the variables are separated in the two groups. The $P$-value may be used to test the significance of this separation and the classification matrix provides an estimate of the accuracy with which individual chromosomes sets can be correctly allocated to the male and female groups. When the direct measurements of the long arms were considered virtually identical results were achieved. The interpretation is that the short and long arms are equally effective in discriminating between male and female cells.

When the total lengths of the chromosomes are used, improvement over using just the short and/or long arm is achieved. Thus overall length is an effective discriminator and its effectiveness is, roughly speaking, equally derived from both its component parts $\left(M_{3}=M_{1}+M_{2}\right)$.

In table 4 the results when the arm ratios are used are given, and in table 5 the centromere indices of the chromosomes are considered. Both these sets of variables are effective discriminators and, in fact, they fare somewhat better than do the arm length measurements. The reason for this is best seen in terms of the mean values of these measurements. While the arm measurements provide a consistent pattern of dif- 
Table 4. Results of the discriminant function analysis when the arm ratios of the chromosomes are used as the set of discriminating variables

\begin{tabular}{llll}
\hline & Male & Female & Total \\
\hline Male & 77 & 23 & 100 \\
Female & 26 & 74 & 100 \\
Mahalanobis & & & \\
Distance & $F$-statistics & $P$-vatue \\
$1.5 !$ & 3.07 & 0.0000 \\
- & &
\end{tabular}

ferences, many of the individual differences are small. On the other hand, while no consistent pattern of differences are in evidence for the ratio measurements, several of the differences for particular chromosomes are quite large, viz., those in the $D$ and $G$ groups. Discriminant function analysis consists of finding linear combinations of the set of discriminating variables which maximally separate the groups under consideration. Thus more weight is given to the ratio measurements in the $D$ and $G$ groups resulting in an effective subset of discriminating variables. In any event, while differences in size are perhaps the easiest to recognize and interpret, the results of these analyses indicate that, in addition to size, differences in shape exist in the male and female samples.

\section{DISCUSSION}

The results provide evidence for autosomal sexual dimorphism in human chromosomes. The female chromosomes are longer overall and with respect to both the short and long arms of each of the 22 autosomes. Significant differences in shape, as reflected in arm ratios and centromere indices, were also found to exist in the D and G chromosomal groups. These differences did not appear when direct measurements were replaced by relative (standardized) measurements, perhaps explaining why other investigators did not notice similar patterns in their data.

On the other hand, the reasons for these differences are not apparent and caution is advised in the interpretation of these results. It could be, e.g., that the size differences merely reflect a sex difference in response to colcemid and not in the length of the chromosomes per se. While this interpretation seems unlikely, and is offered only as an example of possibilities that have not been ruled out during the course of our experimentations, explanations of just why female chromosomes might be longer are equally evasive. There is no theory to explain why male and female autosomes should be different, especially in view of the fact that half of each individual's autosomes are derived from the male parent and half from the female parent. Yet these differences were noted in two separate studies and this evidence is presented here so that others may verify (or refute) these findings and/or offer explanations for the observed differences.

Table 5. Results of the discriminant function analysis when the centromere indices of the chromosomes are used as the set of discriminating variables

\begin{tabular}{llll}
\hline & Male & Female & Total \\
\hline Male & 78 & 22 & 100 \\
Female & 29 & 71 & 100 \\
Mahalanobis & \multicolumn{2}{l}{$\begin{array}{l}\text {-statistic } \\
\text { Distance }\end{array}$} & $\begin{array}{l}P \text {-value } \\
\text { l.60 }\end{array}$ \\
\hline
\end{tabular}




\section{REFERENCES}

1. Barr, M L \& Bertram, E G. Nature 163 (1949) 678.

2. Bender, $M$ A \& Kastenbaum, M A, Am j hum genet 21 (1969) 322.

3. Hamerton, J L, Human cytogenetics. Academic Press, New York (1971).

4. Harris, J E, Nasjleti, C E \& Kowalski, C J, Chromosoma 40 (1973) 269.

5. Jacobs, P A, Brunton, M, Court-Brown, W M, Doll, R \& Goldstein, H, Nature 197 (1963) 1090.

6. Kowalski, C J, Am j phys anthrop 36 (1972) 119.

7. Miller, O J, Mukherjee, B B \& Breg, W R, Trans N $Y$ acad sci 24 (1962) 372.

8. Moorhead, P S, Nowell, P C, Mellman, W J, Battips, D D \& Hungerford, D M, Exp cell res 20 (1960) 613 .
9. Nasjleti, C E, Walden, J M \& Spencer, H H, J nucl med 7 (1966) 159.

10. Paris conference: Standardization in human cytogenetics. Birth defects: Orig. art. ser. VIII (7). The National Foundation. New York (1972).

11. Patau, K, Discussion of methods of human cytogenetics by C E Ford. Methodology in human genetics (ed W J Burdette) Holden-Day, San Francisco (1962).

12. Penrose. L S, Ann hum genet 28 (1964) 195.

13. Seabright, M, Chromosoma 36 (1972) 204.

14. Turpin, R \& Lejeune, J, Les chromosomes humains. Gauther-Villars, Paris (1965).

Received January 20, 1976

Accepted February 9, 1976 